\title{
STRENGTHENING YOUNG GENERATION CHARACTERS IN THE DISRUPTION ERA THROUGH THE INTERNALIZATION OF WAYANG GOLEK VALUES
}

\author{
Abdul Azis, Kokom Komalasari and Iim Siti Masyitoh \\ Fakultas Pendidikan Ilmu Pengetahuan Sosial, Universitas Pendidikan Indonesia \\ E-mail: abdulazis@upi.edu
}

\begin{abstract}
As a adiluhung (valuable art), Wayang Golek performances can contribute to the strengthening of the character of the young generation in facing various challenges in the era of disruption. This is very important, considering that in the era of disruption such as the current challenge for the younger generation in facing the industrial era 4.0 is the loss of character as an Indonesian nation. This study aims to reveal the contribution of Wayang Golek performances values to the strengthening of the character of the younger generation in the era of disruption. The research approach used is qualitative with ethnographic methods, so that it can describe the character values contained in the Wayang Golek performances that are relevant to the character of the Indonesian nation. The results showed that the values of the Wayang Golek performances could contribute to the strengthening of the character of the younger generation. This is because the puppet show is aesthetically designed as an art performance that contains elements of the spectacle as well as guidance. This means, in addition to entertaining through humorous jokes, the Wayang Golek performance is able to give a moral message to the audience about the importance of religious values and nationalism in the face of changing times.
\end{abstract}

Keywords: Wayang Golek; Character Strengthening; Disruption Era.

\section{PENGUATAN KARAKTER GENERASI MUDA DI ERA DISRUPSI MELALUI INTERNALISASI NILAI-NILAI PERTUNJUKAN WAYANG GOLEK}

\begin{abstract}
ABSTRAK. Sebagai sebuah kesenian adiluhung, pertunjukan Wayang Golek dapat berkontribusi terhadap penguatan karakter generasi muda dalam menghadapi berbagai tantangan di era disrupsi. Hal ini sangat penting, mengingat di era disrupsi seperti saat ini tantangan bagi generasi muda dalam menghadapi era industri 4.0 ini adalah hilangnya karakter sebagai bangsa Indonesia. Penelitian ini bertujuan untuk mengungkapkan kontribusi nilai-nilai pertunjukan Wayang Golek terhadap penguatan karakter generasi muda di era disrupsi. Pendekatan penelitian yang digunakan yaitu kualitatif dengan metode etnografi, sehingga dapat menggambarkan nilai-nilai karakter yang terdapat dalam pertunjukan Wayang Golek yang relevan dengan karakter bangsa Indonesia. Hasil penelitian menunjukan bahwa nilai-nilai pertunjukan Wayang Golek dapat berkontribusi terhadap penguatan karakter generasi muda. Hal ini dikarenakan pertunjukan Wayang Golek secara estetis didesain sebagai sebuah pertunjukan kesenian yang mengandung unsur tontonan sekaligus tuntunan. Artinya, selain dapat menghibur melalui lawakan yang jenaka, pertunjukan Wayang Golek mampu memberikan pesan moral terhadap penontonnya mengenai pentingnya nilai-nilai religius dan nasionalisme dalam menghadapi perubahan zaman.
\end{abstract}

Kata kunci: Wayang Golek; penguatan karakter; era disrupsi

\section{INTRODUCTION}

Nowadays, Indonesia's young generation is being faced with the demands of the times which are quite heavy. This is because the changing times that occur very quickly cause concern in the form of the inability of Indonesia's young generation to compete in the development of innovation based on the values of local wisdom. On the other hand - the changing times have had a significant impact on the character of the young generation itself. In a research result showed that moral decadence among the young generation of Indonesia is quite high, among them there are some problems in the midst of technological progress and the emergence of the hedonism lifestyle (Nugroho, 2018).

Penetration of foreign cultures to local cultures that maneuver with the strong development of technology today is a necessity for the Indonesian people. This fact cannot be denied or even avoided by all levels of society in any region. If it is not anticipated wisely, this progress will erode the cultural integrity of the Indonesian nation itself which has always been used as a source of guidelines for community life. The impact that has begun to be felt today is that technological development has not been used wisely by most of the Indonesian people, including the younger generation. Some facts show that technology has not been used wisely by most Indonesians.

The era of disruption is a state full of disruption, innovation, and the threat of the loss of old ways in various fields both social, cultural, educational, economic, has given its own influence especially for the young generation itself (Nugroho, 2018). This can be seen in a number of problems faced by the younger generation as this era of disruption develops. First, the loss of the character of the younger generation by the influence of the use of social media. Excessive use of social media impacts the lifestyle of hedonism (Azis, Komalasari and Masyitoh, 2017). Secondly, the erosion of the value of local wisdom which has been used as a source of value for the Indonesian people (Azis, Komalasari and Masyitoh, 2017). Meanwhile, the values embodied in the local wisdom of the Indonesian people clearly represent religious values and nationalism. 
Based on the above description, awareness of efforts to reflect the values of local wisdom needs to be done massively towards the younger generation. This is done as a preventive measure so that the young generation of Indonesia does not lose its identity as an Indonesian nation that is characterized by facing challenges in the era of disruption. One of the efforts that can be done, among others, is by planting character values for the young generation of Indonesia through the puppet show. Puppet show is an original art and culture of Indonesian society which has a number of values that reflect the nation's personality (Sabunga, Budimansyah and Sauri, 2016).

Seeing the essence of the puppet show above - there are at least two reasons that can strengthen the importance of the Puppet Show being used as a reinforcement of the character of the young generation of Indonesia. First Gol The Wayang Golek performance functions as a spectacle. This means that the Wayang Golek performance is able to provide entertainment through the aesthetics of the presentation of the storyline, the characterizations and characters of each character displayed. Second, The Wayang Golek functions as a guide. Through the portrayal of the wisdom of the puppet figures and antawacana (dialogue between characters) that are delivered in every storyline - puppet show presents philosophical values that represent religious values and nationalism. This indirectly provides an experience that can be reflected in the lives of Indonesia's young generation.

In view of the above, it can be assumed that the Wayang Golek performance is very important to be used as a reinforcement of the character of Indonesia's young generation in this era of disruption. Concerns about the erosion of the character and personality of Indonesia's young generation in undergoing changing times can be overcome by efforts to instill the values of the characters contained in the Wayang Golek performance. Moreover, there are research results that show about the innovation of making an application-based virtual puppet show (Zaini, 2014). The result of this research is an innovation developed along with technological developments perkembangan so that the existence of the Wayang Golek performance as a local wisdom can be developed by adjusting the association of the younger generation.

Besides that Way Wayang Golek performances can also be used as media as well as learning resources for students at school. This has been done by the authors in previous studies which showed that the Wayang Golek semiotic performances can be used as a learning resource for Citizenship Education for students through contextual learning processes that prioritize reflexive learning between learning material and the experiences of students (Azis, Komalasari and Masyitoh, 2017). Meanwhile, in another study it was stated that Wayang Golek can be developed as a learning medium for junior high school students in social studies learning (Saripudin and Komalasari, 2016).
Based on the description above, it is interesting to study the values contained in the Wayang Golek performance as an effort to strengthen the character of the young generation of Indonesia in facing challenges in the era of disruption. Because in some of the findings of this disruption era is quite influential and has a significant impact on the rise of moral decadence caused by a lack of moral awareness and a strong character in wading through the changing times (Binov, 2010).

\section{METHOD}

This study uses a qualitative approach with the method used namely ethnography. This method is used with the aim of describing, analyzing, and interpreting elements of a cultural group such as patterns of behavior, beliefs, and language that develop over time (Cresswel, 2013). In the context of this study, the use of ethnographic methods was carried out with the aim of describing the character values contained in the Wayang Golek performance to be used as a reinforcement of the character of Indonesia's young generation in facing challenges in the era of disruption.

In conducting research, researchers conducted interviews as well as observations on several research subjects, including activists of the Wayang Golek show, previous researchers who have conducted research on puppet show performances and teachers. The data obtained during carrying out the research are then presented in the form of data triangulation and an in-depth and comprehensive analysis using theories and previous research findings related to this research.

\section{RESULTS AND DISCUSSION}

\section{Overview of the Young Generation in the Disruption Era}

The rapid changes in various aspects of both social, cultural, political and technological influence on the behavior patterns of Indonesia's young generation today. Based on the results of research conducted on Citizenship Education Teachers at SMAN 1 Baleendah, obtained information that the young generation of Indonesia, especially among high school students, relatively showed changes in social and academic relationships including: 1) the development of westernization into the behavior of the younger generation ; 2) a hedonistic lifestyle; and 3 ) the loss of cultural roots as the main source of value in developing the character of students. This is also in line with the results of research that explains that the era of disruption such as now causes a situation where the values of hedonism that develop from western teachings eliminate the love of students' homeland because it is more dominant or has polluted their minds with western cultures, especially damaging adolescents (Binov, 2010).

Some of these problems occur due to the lack of anticipation of the younger generation in facing 
various changes. In addition, the loss of knowledge and understanding of character values based on local wisdom also have an impact on changes in the behavior patterns of the young generation. Because character values based on local wisdom are living values that can be developed in the learning of students in schools (Saripudin and Komalasari, 2016).

Based on the results of the study, it can be raised several issues that describe the current condition of the younger generation. The first problem related to the condition of the younger generation in this era of disruption is behavior that tends to act western. Through students' presentation, teachers as the participants said that this behavior was reflected by students as the younger generation whether in and outside of school. For instance, in everyday social relationships, they tend to be westernized in terms of language, dressing and socialisation (Azis, Komalasari and Masyitoh, 2017). This behavior tends to make students lose their religious values as well as their nationalism as an Indonesian nation. Therefore, it is necessary to integrate an educational model that emphasizes the principles of life values based on local wisdom. As explained in a study that this model is conceptually a learning need to integrate the values of life and the principles of life value education into interactive multimedia (Komalasari and Rahmat, 2019). This needs to be done so that in navigating technological developments in this era of disruption can be anticipated wisely through education. Thus, students as young generation will not lose their identity as Indonesian people who are religious and love the motherland.

The second problem is related to a hedonist lifestyle. This behavior can be described from the behavior of students in following learning. The spirit in participating in learning tends to be less enthusiastic. This is inseparable from the lack of wisdom of students in anticipating technological change. In practice, students are more likely to enjoy playing online games or playing social media when learning in class. Participating in learning tends to be lazy because it is lulled by the many features presented by social media or online games. Meanwhile, in the national education goals, the government has set 18 characters that need to be possessed by students, some of whom care about the environment - hard work - independent - religious and patriotism (Department of National Education, 2003). For example - now the government is conducting a Citarum Harum program to restore the function of the Citarum River which requires the help of all parties (Resnawaty and et al, 2019). With this program, students as a young generation must show the character of their concern for the environment rather than just playing social media or online games.

The last problem is at the same time a fundamental problem over the previous problem, namely the loss of the cultural roots of Indonesia's young generation which should be the basis for behavior. This behavior has a tendency to be more proud of westernized behavior than to behave based on the local wisdom values of the Indonesian people themselves. The impact of the behavior of young people in schools tends to be far from the religious values and patriotism that has been contained and integrated in the values of local wisdom. As stated in a study that the problems of the Indonesian people that often occur today include the degradation of the nation's moral values which is very alarming among the younger generation (Sabunga, Budimansyah and Sauri, 2016).

With regard to the above - one of the alternatives in addressing this problem is the development of the concept of ethnopedagogy by Alwasilah, et. al. in 2009 which aims to develop a learning atmosphere that integrates the values of local wisdom in it (Suratno, 2010). In addition, ethnopedagogy in elementary schools needs to be implemented with innovative learning strategies and media that are able to attract the attention of students to understand and apply local wisdom (Oktavianti and Ratnasari, 2018).

In West Java, various values of local wisdom that grow and develop in the community quite a lot. Of course this can support the development of an ethnopedagogical concept in learning in schools so that the values of local wisdom can be integrated into the behavior of students in the face of the era of disruption. One of them is the Wayang Golek performance. One of the local wisdoms of this Pasundan land - besides being a tontontan means - is used as a means of guidance for the community (Azis, Komalasari and Masyitoh, 2017). Because the Wayang Golek show is presented aesthetically with an entertaining packaging but still prioritizes character values that can be transformed to the audience.

\section{Analysis of Character Value in Wayang Golek Show}

The puppet show is a dramatic art performance that presents a story visualized through wooden dolls resembling humans in both their shapes and characters. Besides that, Wayang Golek is not only as a component of art that aims to fulfill biological satisfaction but also aims to fulfill inner satisfaction in the form of visual puppets is a process of introspection that is intuitive to the symbols of human life accompanied by intellectual and moral elements (Hadijah, 2012).

Based on the results of observations made on the performances as well as the manuscript documents of the Wayang Golek story show, it was found that the essence of the Wayang Golek performance is an art with a content substance that represents everyday human life. In general, the story plays Wayang Golek mostly depict the background of national and state life, conflicts involving Wayang Golek figures, to problem solving interspersed with the emergence of Punakawan so as to provide an entertaining atmosphere while providing guidance for the audience. The substance of these values can be seen in a number of stories that although conceptually lifted from 
the stories of the past, but in substance have not been obsolete and are still in accordance with the context of community life in the present (Sabunga, Budimansyah and Sauri, 2016). In addition, the audience will be able to sort out the good and evil characters and reflect them into today's life.

In general, the character values in the Wayang Golek performances are contained in every part of the Wayang Golek performances including: 1) the shape and appearance of the Wayang Golek; 2) meaning of linguistic aspects; and 3) The value of the substance in a play. The details are described in the following table.

\section{Table 1. Substance of Character Value in Puppet Show}

\begin{tabular}{cl}
\hline $\begin{array}{c}\text { Performance } \\
\text { Aspects }\end{array}$ & \multicolumn{1}{c}{ The Substance of Character Value } \\
\hline Shape and Fine & $\begin{array}{l}\text { The appearance of the Wayang Golek } \\
\text { appearance contains character values that } \\
\text { are semiotically shown through the shape } \\
\text { of the eyes, nose and mouth. The value } \\
\text { contained in the wayang golek appearance } \\
\text { can give a picture of human nature in } \\
\text { general, that is a good human being and an } \\
\text { evil human being. } \\
\text { The linguistic aspects of the Wayang Golek } \\
\text { performance can generally be found in } \\
\text { the opening song, murwa, nyandra and } \\
\text { antawacana sections. In general, the } \\
\text { content of the character values that are } \\
\text { semiotically contained in the linguistic } \\
\text { aspect contains discourses that reflect the } \\
\text { relationship between humans and humans, } \\
\text { humans with the environment, humans } \\
\text { with nature, and humans with God to be } \\
\text { realized in daily life expressed through } \\
\text { speech } \\
\text { The substance of the story can provide a } \\
\text { presentation of events that reflect everyday } \\
\text { human life. This is reinforced by the visual } \\
\text { and linguistic aspects accompanied by } \\
\text { sabetan and pirigan, so that it can provide } \\
\text { character values for the audience. These } \\
\text { character values include the character } \\
\text { of homeland love (in the Kumbakarna } \\
\text { Fall) and the character defending truth or } \\
\text { religion (in the Bayu Suta Pawana play) }\end{array}$ \\
\hline Plaspects
\end{tabular}

Source: Data processed by Researchers (Azis, et. al,2019).

In the first aspect, namely the form and appearance aspects of the puppet show there are several character values that can be used as character development for the younger generation in the era of disruption. Because every puppet character has his own character and character as a reflection of his audience. The philosophical values of life in the puppet show are conveyed through the character or character of the puppet character which is a reflection or representation of the attitudes, character, and character of humans in general (Sabunga, Budimansyah and Sauri, 2016).

Meanwhile, in linguistic aspects, we can find character values in some fragments of Murwa, Nyandra, Kakawen or antawacana texts. As in the quote of the opening song titled Kembang Gadung in the Wayang

Golek show as follows.

Bismilah bubuka lagu
muji sukur ka Hyang Agung
sumembah ka sang karuhun
sumujud ka Batara Agung
neda widi neda amit
ka Gusti Nu Maha Suci
mugi diaping dijaring
neda pangraksa pangriksa
sareng ka para karuhun
nyanggakeun ieu pangbakti duh Gusti
ulah bade hiri dengki
duh alah. . .
kembang gadung nu kahatur
nyanggakeun ieu pangbakti
pangbakti ti seuweu-siwi.

Based on the fragment of the song, at least the researcher can reveal that the opening song in the Wayang Golek performance has semiotic values embedded through the language expression or song lyrics. There are at least three moral messages that can be received by the audience in the opening song of the Wayang Golek performance, namely: a) praise to God Almighty; b) remind people to always be aware of God's pleasures to be thankful for; and c) pay homage to the ancestors (karuhun) by praying for them to get happiness in the grave and hopefully in the hereafter to heaven.

Furthermore, at the time of Murwa and Nyandra, the puppeteer provides information to the audience about the setting / setting of the story and the characters involved through a song that is sung by the puppeteer which contains an explanation of the story that will be displayed with the content in each temple. The contents of these values mostly contain religious elements which signify a human recognition of God's greatness as the creator of the universe (Sabunga, Budimansyah and Sauri, 2016). Next is the fragment of murwa Dalang in the Wayang Golek performance.

Nyalindung abdi ka Alloh tina pirang-pirang godaan setan anu diranjam. Kalayan nyebat asmaning Alloh anu kagungan sifat murah sareng sifat asih. Maksad nyarioskeun lalampahan pawayangan, anu pinuh $k u$ perlambang hirup manusa nu gelar di Marcapada. Anu dipipindingan $k u$ silib, sindir, dihalangan ku siloka, sasmita. Anu diharimunan ku simbul, guareun manusa jaman kiwari. Anu aya patulapatalina sareng kawajiban manusa, yen manusa teh diwajibkeun tafakur, tadakur sareng tasyakur. Margi ieu lalampahan pawayang teh teu kirang sareng teu langkung nyarioskeun salah jeung bener, adil jeung murka. (in Lakon Cepok Kembar)

The fragment of the puppet mastermind above contains religious elements which in this case can be 
seen through the expression of the puppeteer at the time of praising God who has a loving and compassionate nature for human protection from all forms of cursed Satanic temptations. Through recognition of the greatness of God that the mastermind tries to invite the audience to understand the symbolic values which are symbolic of the behavior of human life at this time related to the obligation of humans to contemplate, act and thank God (Sabunga, Budimansyah and Sauri, 2016). Through the murwa puppeteer also the puppeteer asserted that the lack and excess of the Wayang Golek show tells of right and wrong as well as fairness and wrath that is reflected in human life today.

Meanwhile, Based on the results of research conducted by researchers, a number of story plays have been presented in a puppet show as follows.

a. The play "Kresna Duta" which contains a moral message to love peace and deliberation. The story is told that each protagonist considers war as a last resort to solve problems. That is, if there is still the best way by making peace then that is what must be chosen;

b. The play "Subali Pejah" which contains the character of tolerance and preserves unity and integrity. The story is told about a fight over power involving two brothers, namely Subali (older brother) and Sugriwa (younger brother).

c. The play "Dewi Nila Ningrum" which contains the value of patriotism. In the play Semar Badranaya was told who pretended to marry Dewi Nila Ningrum in order to save the Heritage of Jamus Kalimusada, which was a symbol of the greatness of the State of Amarta from the target of the wrath of Prabu Durgala Pati.

d. The play "Kumbakarna Fall" which contains the character of the spirit of nationalism and love for the country. In that play, Arya Kumbakarna led the war against King Ramawijaya in order to defend the Alengkadirja State from being trampled by the enemy.

e. The play "Bayu Suta Pawana" which has the substance of the value of patriotism, deliberation and defending the truth. The story is told that Prabu Duryuduna discussed with Bhishma Receipt, Drona Receipt, Arya Sangkuning and other Kauravas to find a way out to overcome the multidimensional crisis that hit the State of Astina. In the meeting the Bhishma Receipt, Drona Receipt, Arya Sangkuning and other kurawa instigated Prabu Duryuduna to take Semar Badranaya's brain as a cure for the multidimensional crisis of the Astina state. On the one hand, Bayu Suta Pawana which is an embodiment of Anoman wants to save Semar Badranaya from the Denavas and the Kauravas who intend to make Semar Badranaya (Azis, Komalasari and Masyitoh, 2017).

\section{Internalization of Wayang Golek's Character Value in Strengthening the Character of Young Generation in the Disruption Era}

Talking about regeneration in a nation is inseparable from the role of the young generation that live in the nation. They position as the successor to the ideals of the nation's struggle, so that the future of a nation lies in the younger generation as they will replace the previous generation in leading the nation (Hasibuan, 2008). In the context of this study, what researchers meant as the younger generation are students in SMAN 1 Baleendah. The choice of the younger generation is inseparable from the inherent expectations of them to continue their leadership in the future as educated people. Besides, students as young generation are always associated with the concept of values and character as the main capital needed to become a quality generation of the nation in the future. As UNESCO (United Nations, Educational, Scientific and Cultural Organization) launched four pillars of Education including: 1) Learning to know; 2) Learning to do; 3 ) Learning to be; and 4) Learning to live together, which is an achievement in the learning process in schools in order to shape the character of students as young people (Laksana, 2016).

In line with the description above, The Government through the Ministry of National Education has declared 18 national character values that must be internalized to students in organizing character education in schools including: religious; honest; tolerance; discipline; hard work; creative; independent; democratic; curiosity; spirit of nationalism; love the motherland; reward achievement; communicative; love peace; like to read; environmental and social care and responsibility (Ministry of National Education, 2003), which are integrated into curricular and extracurricular programs. This is done as an effort to turn students into characterized young generation. Therefore, it is necessary to establish the character values that are collaborated with the values of local wisdom in Indonesia, one of which is through the Wayang Golek performance.

Based on the analysis of character values contained in the previous Wayang Golek performances, it was obtained a result that the character values can be internalized to strengthen the character of the younger generation in the era of disruption through learning Citizenship Education in schools. In general, the strengthening of character can be given into three aspects, including aspects of knowledge, attitudes and skills. This is in accordance with the concept of living value-based learning that emphasizes the reflective process of life values towards strengthening students' competencies (Komalasari, 2012).

Citizenship Education or better known as citizenship education is one of the compulsory subjects in the 2013 curriculum at every level of education, from basic education to higher education. This is reinforced by Article 37 paragraph (1) of Law Number 20 Year 2003 concerning the National Education System which places Citizenship Education as a subject that has the role of forming students into human beings who have a sense of nationality and love for the motherland. In line with 
an opinion which states that Citizenship Education is an education/learning program that is programmaticallyprocedurally seeks to humanize and civilize and empower students/students (themselves and their lives) to become good citizens as demands must/juridical constitutional nation / state concerned (Djahiri, 2006).

Therefore the implementation of Citizenship Education learning inschools should notonly requirestudents to understand Citizenship Education cognitively, but can also instill the ability of attitudes and skills that characterize the sense of nationality and love of the motherland in students. As stated, the purpose of civic education emphasizes quality and responsible participation in political and community life, both at the local and national level (Komalasari, 2011). Furthermore the level of participation and responsibility is influenced by citizenship competencies in the form of: a) mastery of certain knowledge and understanding; b) development of intellectual and participatory abilities; c) development of certain characters or mental attitudes; and d) true commitment to the values and fundamental principles of constitutional democracy.

Based on the results of research conducted by researchers, both through interviews and observations of the Citizenship Education teacher at SMAN 1 Baleendah, obtained information that Citizenship Education learning carried out in schools has not been able to touch the three domains of educational goals (cognitive domain, affective domain and psychomotor domain) as a whole. intact. This is motivated by the implementation of Citizenship Education learning which seems to only focus on mastering learning material. In its implementation, there are still limitations of the teacher in developing the learning model so that it can touch the three domains of education to be achieved.

Another factor shows that the teacher feels the need to provide a dominant explanation of the material so that students are able to understand the contents of the material in order to make it easier for students to take the test when evaluating Citizenship Education learning. Coupled with the small amount of time available in each week with only two hours of duration, the teacher feels the need to explain more material. On the other hand, the implementation of Citizenship Education learning in schools today is still teacher center learning.

Learning patterns like this can cause the dominant teacher to use the lecture method on Citizenship Education learning, so students can only listen to the material from the teacher. Of course this is contrary to the principle of learning itself, which is essentially learning to develop students' activities and creativity, through various interactions and learning experiences (Mulyasa, 2002). In this case the interactive atmosphere between students and teachers in operationalizing learning components such as material, media, methods, sources and evaluation of learning.

Departing from the problems of implementing Citizenship Education learning at this time that has not been able to touch the three domains of education, this study seeks to provide an alternative in the form of ethnopedagogy-based learning model development. The aim of developing this ethnopedagogy-based Citizenship Education learning is aimed at achieving the sociopedagogical and formal-pedagogical vision of Citizenship Education. The construction built in this research involves the object of semiotic study which is used as a point of view in interpreting the values inherent through the symbol in the puppet show Golek. Through the process of interpretation (semiosis) that students are expected to reflect the valuable values contained in Wayang Golek in order to be able to understand their rights and obligations as citizens.

Substantially, the Wayang Golek performance is a local wisdom of Sundanese people which is full of religio-cultural values. The contents of these values are semiotically embedded through symbols that appear in every element in the Wayang Golek performance. As well as a study of strengthening the nation's character through the Purwa Wayang Golek show that the Wayang Golek performances that are delivered are full of nuances of character values which are manifestations of human love for God. Good values conveyed through wayang golek purwa performances are oriented to fostering community behavior in an effort to advance the life of the nation and state. The substance of character values conveyed through the wayang golek purwa show is classified into three types, namely the main character, basajan and selapan (Sabunga, Budimansyah and Sauri, 2016).

Referring to the description above, the puppet show can be used as a source of learning in the development of ethnopedicogy-based Citizenship Education learning. As expressed by an opinion that cultural values that can be explored and in accordance with the florescence of the times are the values of education which are part of ethnopedagogy (Hamdani, 2015). The idea of integrating the semiotics of the Wayang Golek performance developed in Citizenship Education learning is nothing but a form of developing the socio-pedagogical and formalpedagogical vision of Citizenship Education itself. As a curricular program in formal education, the integration of semiotic values in the Wayang Golek performance into the learning of Citizenship Education is an effort to strengthen the identity of Citizenship Education itself. Innovations developed through the development of learning resources for students contain substance in the form of learning content that can develop learning materials and learning experiences.

The development of learning materials as well as the learning experiences of the students themselves were obtained through the footage of Wayang Golek performances as a stimulant. This is because as a valuable art, puppet show is not just a spectacle, but also as a guide. Thus, it is expected that participants will be encouraged to understand their rights and obligations as democratic 
citizens to be able to participate in social-cultural action programs in the social context.

In the present context, it is stated that in order to achieve the socio-pedagogical and formal-pedagogical vision, Citizenship Education has a socio-pedagogical, socio-cultural, and substantive-academic mission (Winataputra and Budimansyah, 2006). The three missions are the embodiment of the socio-pedagogical and formalpedagogical vision of Citizenship Education, which in this case is to be achieved through the development of Citizenship Education learning by integrating Wayang Golek performances into the learning of Citizenship Education in schools.

Furthermore, the various symptoms of moral decadence that plague young people today require all elements, especially Citizenship Education teachers to enhance the development of various approaches that are felt to be able to overcome these problems. At present the focus of Citizenship Education learning should not only be focused on the printing of young people who are of cognitive quality. More than that, the cognitive quality of students today must also be balanced with the ability of attitude and skills. This is in accordance with the purpose of civic education itself which requires quality and responsible participation in political and community life, both at the local and national levels that require citizenship competencies in the form of: a) mastery of certain knowledge and understanding; b) development of intellectual and participatory abilities; c) development of certain mental characteristics or attitudes; and d) true commitment to the values and fundamental principles of constitutional democracy (Barber, Sweetwood and King, 2015). The citizenship competency is further classified into three things, namely civic intelligence (Civic Intelligence), fostering civic responsibility (Civic Responsibility) and encouraging civic participation (Civic Participation). The three competencies of citizens are in line with the three components of good civic education, namely Civic Knowledge, Civic Skills, and Civic Disposition.

Departing from the above description, the results of the research previously presented provide an alternative related to the implementation of Citizenship Education learning in schools. In this case the proposed alternative is in the form of the development of ethnopedagogy-based Citizenship Education learning with puppet show as its main source of learning. Basically, the development of this kind of ethnopedagogy-based learning is done in order to make it easier for teachers to deliver the material and make it easier for students to accept and understand the material. The development of this kind of Citizenship Education learning is a synergistic civic culture social movement carried out in an effort to build "civic virtue" and "civic culture" through active participation in an intelligent, democratic and religious manner in its environment (Winataputra, 2014).
The design of learning is emphasized in this case by making learning centered on students. This is done so that students can gain new learning experiences and provide more space for students to explore Citizenship Education learning materials. Moreover, ethnopedagogybased learning through the Wayang Golek performance developed in this research emphasizes more on Citizenship Education learning that can develop citizenship competencies in learners.

Based on the foregoing, the ethnopedagogy-based Citizenship Education learning is carried out by integrating values in the puppet show during the learning process. This is done by making the puppet show Golek as a source of learning. There is also in general, the implementation of learning has been described previously by implementing student-centered learning patterns. In practice, footage from the Wayang Golek that is displayed in learning is used as a tool to analyze the learning materials being discussed. Departing from the steps of integrating and implementing, learning ethnopedagogy-based Citizenship Education is expected to foster citizenship competence towards students namely Civic Knowledge, Civic Skills, and Character or Civic Disposition.

When viewed from the learning objectives developed in this, it can be seen that the current Citizenship Education is confronted with the context of the reform process towards a new Indonesia with the concept of civil society as its socio-cultural ideal order. Thus the citizenship education developed has a mission: (1) sociopedagogical; (2) socio-cultural; and (3) substantiveacademic (Winataputra, 2008). The socio-pedagogical mission in Citizenship Education itself is explained as developing the potential of individuals as individuals of God and social beings to become intelligent, democratic, law-abiding, civilized and religious Indonesian citizens. The correlation that is built with this research can be seen in research on character education based on ethnopedagogy in the context of modern education directed at fostering the character of students. The research seeks to adopt two types of conventional educational patterns that rely more solely on individuals as in the growth process of students both physical and psychological growth, which will only result in students losing in an era that is complex, dynamic and global (Azis, Komalasari and Masyitoh, 2017).

Meanwhile in the socio-cultural mission, the development of ethnopedagogy-based Citizenship Education facilitates the realization of ideals, belief systems / values, concepts, principles, and praxis of democracy in the context of the development of Indonesian civil society through the development of citizens' participation intelligently and responsibly through various social activities -cultural creative that boils down to the growth and development of the moral and social commitment of citizenship. This can be instilled in students through Wayang Golek performances that can transform the values in it. Whereas the substantive-academic mission 
seen in this research is to develop the structure or body of citizenship education knowledge, including concepts, principles, and generalizations about and with regard to civic virtue or the virtues of citizenship and civic culture or civic culture through civic research and development activities ( epistemological functions) and facilitate sociopedagogical and socio-cultural praxis with the results of their research and development (axiological functions).

Firstly, internalization of the values of Wayang Golek performances can be carried out to enhance the knowledge of Indonesian young generation. In this era of disruption, internalization of character values can be obtained through Wayang Golek storytelling, which substantively tells a lot about community, national and state life can strengthen learners' understanding, including knowledge of the importance of religious values and the love of the motherland in the face of an era of disrupted laden disruption. for this challenge. Substantially, one's knowledge is very influential on one's thinking and action patterns (Langford, 2018).

Secondly, the internalization of the Wayang Golek performance towards increasing the attitude of Indonesia's young generation in the era of disruption, that the Wayang Golek performance provides reflection through moral messages that contain a reflection that reflects the relationship between humans and humans, humans with the environment, humans with nature, and humans with God to be realized in everyday life. This can encourage self-confidence, commitment, mastery of religious values, norms and noble morals, the value of justice, democratic and tolerance in young people in facing the challenges of the era of disruption.

Thirdly, the internalization of the Wayang Golek performance on improving the skills of Indonesia's young generation in the era of disruption can stimulate students to have the skills to participate in the life of the nation and state, especially to actively participate in realizing civil society, the skills to influence and monitor the running of government and political decision-making processes, dismissal skills social problems, coalition skills, cooperation, conflict management, and life skills, which are realized through innovation and creativity to work based on local wisdom values through a process of analysis and reflection on the values in the Wayang Golek Performing Story story.

\section{CONCLUSION}

Based on the results of research, it can be summarized that the current era of disruption is characterized by the rapid development of technology and the students' dependence on the use of social media. On the other hand, this affected the behavior patterns of the younger generation, most specifically, the students themselves. At least the changes in behavior experienced by the younger generation today include: the existence of westernization behavior; a hedonistic lifestyle; and the loss of the cultural roots of Indonesia's young generation. Therefore, Wayang Golek show can be used as a medium to strengthen the character of the young generation of Indonesia. This is because the Wayang Golek performances can provide a reflective moral message and represent a daily human life that is aesthetically packaged so that it can strengthen the religious character and nationalism of Indonesian youth.

\section{REFERENCES}

Azis, A., Komalasari, K. \& Masyitoh, I.S. (2017). Semiotics of Wayang Golek Giriharja Art Show As a Learning Source of Civic Education, Scientific Journal of Pancasila and Citizenship Education, 2,(2), 91-97. doi: 10.17977/um019v2i22017p091.

Barber, C., Sweetwood, S. \& King, M. (2015). Creating classroom-level measures of climate education citizenship, Learning Environments Research, 18, 197-216 https://10.1007/s10984-015-9180-7.

Binov, H. (2010). The Role of Education in Building Nation Morality, in the Role of Education in Building Nation Morality, Conference Proceeding pp. 41-52.

Cresswel, J. (2013) Qualitative, quantitative, and mixed methods approaches. Research design, 33, (2) 252255 https://doi.org/10.2307/3152153

Department of National Education (2003). Law No.20 of 2003 about National Education System, Jakarta: Ministry of National Education.

Djahiri, A.K. (2006). The Essence of Moral Value Education and Civics in the Era of Globalization, in Moral Value Education in the Dimensions of Citizenship Education. Welcoming 70 Years of Prof. Drs. HA. Kosasih Djahiri. Bandung: Lab. FPIPS UPI.

Hadijah. (2012). Comparative Study of Purwa Wayang Golek Typical Kuningan and Sumedang, West Java in Semiotic Analysis 2007 to 2010, Catharsis: Journal of Arts Education, 4, (2), pp. 123-129.

Hamdani, M.Y. (2015). Children's Games in Conggeang District, Sumedang District (Structural and Ethnopedagogical Study). Journal: Lokabasa, 6, (2), 135-140.

Hasibuan, M. (2008). Human Resource Management. 11th print. Jakarta: PT. Bumi Aksara

Komalasari, K. (2012). The Living Values-Based Contextual Learning to Develop the Students Character, Journal of Social Sciences. 8, (2), 246-251

Komalasari, K. \& Rahmat (2019) 'Living Values Based on Interactive Multimedia in Civic Education Learning, International Journal of Instruction, 12, (1), 113-126. 
Komalasari, K. (2011). Contextual Learning Contribution for the Development of Citizenship Nationality Competence of Middle School Students in West Java. MIMBAR Journal, XXVII, (1), 47-55.

Laksana, S.D. (2016). Integration of the Four Pillars of Education (UNESCO) and the Three Pillars of Islamic Education. Jurnal Kependidikan Islam, 6, (1), 41-60. DOI: https://doi.org/10.24042/alidarah. v6i1.789

Langford, P. E. (2018) Approaches to the Development of Moral Reasoning, Approaches to the Development of Moral Reasoning. London: Psychology Press page 156, doi: 10.4324/9781315791258-5.

Mulyasa, E. (2002). Competency Based Curriculum (Concept, Characteristics, Implementation). Bandung: Teen Rosdakarya.

Nugroho, I.S. (2018) Eks Existential-Humanistic Approach based on Javanese Culture values "narimo ing pandhum" to reduce teenage anxiety in the era of disruption, National Seminar on Guidance and Counseling, 2 (1), pp. 46-54.

Oktavianti, I. \& Ratnasari, Y. (2018). Ethnopedagogy in Learning in Primary Schools through Local Wisdom-Based Media, Educatic Reflections: Educational Scientific Journal, 8, (2), 149-54. doi: 10.24176/re.v8i2.2353.

Republic of Indonesia Law No. 20 of 2003 concerning the National Education System.

Resnawaty. (2019). Business Contribution in the Implementation of the Citarum Harum Program (Case Study of the Implementation of the Electricity Company CSR in Supporting the Fragrant Citarum Program), Sosiohumaniora 21 (3), 279-286. doi: 10.24198/sosiohumaniora. v21i3.20206.
Sabunga, B., Budimansyah, D. \& Sauri, S. (2016). Character Values in Purwa Puppet Show Performance, Jurnal Sosio Religi, 14, (1), 1-14.

Saripudin, D. \& Komalasari, K. (2016). Culture-based contextual social studies learning for development of social and cultural values of junior high school students', Social Sciences (Pakistan). 23,(11), 5726 -5731, doi: 10.3923/sscience.2016.5726.5731.

Suratno, T. (2010). Understanding Ethnopedagogy as the Foundation of Teacher Education at the Indonesian University of Education. In Proceedings of the 4th International Conference on Teacher Education; Join UPI \& UPSI Conference 8-10 November 2010, page 515-530.

Winataputra, U.S. (2014). Actual Discourse About Citizenship Education Paradigm (PKn) In the Context of Curriculum 2013, page 1-12 on AP3KNI National Seminar.

Winataputra, U.S. (2008). Multiculturalism-Unity in Diversity in the Perspective of Citizenship Education as a Forum for the Development of the Character of the Indonesian Nation, Journal Pendidikan dan Kebbudayaan, 14, (74) 10091027 doi:10.24832/jpnk.v14i75.364.

Winataputra, U.S. \& Budimansyah, D. (2006). Civic Education: Context, Platform, Teaching Material and Class Culture. Bandung: UPI Graduate School Citizenship Education Study Program, page 215. Online Access: http://kin. perpusnas.go.id/DisplayData.aspx?pId $=40479 \&$ pRegionCode $=$ UNES\&pClientId $=634$.

Zaini, T.M. (2014). Development of Computer-Based Virtual Wayang Puppet Art With Opened Software, Journal of Informatics, 10 (1), 58-69. 